\title{
Magi och nation
}

Häxor i finländsk och svensk 1800-talslitteratur ${ }^{1}$

Magi och MEdborgarskap disKuteras vanligtvis i skilda sammanhang. I finländsk och svensk litteratur från mitten av I8oo-talet ställs emellertid häxor och medborgare i direkt relation till varandra. Bonden har ofta lyfts fram som företrädare för folket, men denna artikel visar att även häxan fick representera nationen på olika sätt i litteraturen vid mitten av I80o-talet. I århundraden hade stat och kyrka brännmärkt trolldom som en pakt med Satan, som onda makters sätt att verka i världen. Under I8oo-talet förändrades förståelsen av ondskans problem - liksom förståelsen av folket.

"Folket" gavs olika innebörder i olika politiska läger. I såväl liberala nationalistiska demokratiseringsrörelser som i konservativ "officiell nationalism" var dock begreppen "folk" och "medborgare" centrala. ${ }^{2}$ Det moderna medborgarskapsbegreppet var vid mitten av i8oo-talet fortfarande under konstruktion. ${ }^{3}$ Det uppfattades i hög grad som en

I. Artikeln ingår i forskningsprojektet Förtrollande nationer: varumarknad, folktro och nationalism i skandinavisk skönlitteratur 1830-1850, finansierat av Riksbankens Jubileumsfond 20I6-20I8. Jag har presenterat tidigare utkast av denna artikel på I80o-talsseminariet vid History Faculty, Oxford University, Scandinavian Studies vid University of Edinburgh, Nordeuropa-Institut vid Humboldt-Universität zu Berlin samt Finska, finskugriska och nordiska institutionen vid Helsingfors universitet. Jag vill tacka alla - särskilt seminariet i nordisk litteratur vid Helsingfors universitet - för viktiga synpunkter och produktiva frågor.

2. Matti Klinge, Den politiska Runeberg, Stockholm: Bokförlaget Atlantis / Helsingfors: Söderströms 2004, s. 87-I24, se särskilt s. 95; Matti Klinge, Idyll och hot. Zacharias Topelius - hans politik och idéer, övers. Nils Erik Forsgård, Stockholm: Bokförlaget Atlantis / Helsingfors: Söderströms 200o, s. 274, 279, 290 f.

3. Exempelvis kodifierades villkoren för medborgarskap i svensk lag först i858. Ebba Berling-Åselius, Rösträtt med förbinder. Rösträttsstrecken i svensk politik 1900-I920, Stockholm: Acta Universitatis Stockholmiensis 2005, s. 24. 
moralisk kategori - och som manligt konnoterat. Jørgen Lorentzen och Claes Ekenstam inskärper att tanken med de nya medborgarnationerna var att "medborgarnas olika egenskaper tillsammans konstituerade nationalkaraktären, det vill säga nationens politiska förmåga stod i direkt förbindelse med de individuella medborgarnas (männens) förmåga att kultivera sina medfödda och förvärvade egenskaper”. ${ }^{4}$ Finska och svenska kvinnor hade ännu långt kvar till politisk rösträtt, men de var trots allt medborgare, om än med Kathryn Gleadles ord "'borderline' citizens". ${ }^{5}$ Kvinnliga författare som Fredrika Bremer och Sara Wacklin, men även vissa manliga författare som Zacharias Topelius och Carl Jonas Love Almqvist, insisterade på att även kvinnors bidrag till nationen skulle räknas. ${ }^{6}$ Här spelar magi en framträdande, och för vår tid förvånande, roll.

I denna artikel studeras häxor i svenskspråkig litteratur från mitten av I80o-talet. Undersökningen gör inte anspråk på att vara heltäckande, utan avser att analysera relationen mellan magi och nation hos fyra populära författare. ${ }^{7}$ I Zacharias Topelius Hertiginnan af Finland (I850) drivs intrigen i romanens andra del av den magnifika häxan Waapuri. Berättelsen publicerades först som följetong, men i den omarbetade bokutgåvan utgör första delen en redogörelse för krigs-

4. Jørgen Lorentzen \& Claes Ekenstam, "Inledning”, Jørgen Lorentzen \& Claes Ekenstam (red.), Män i Norden. Manlighet och modernitet 1840-1940, Hedemora: Gidlunds förlag 2006, s. II.

5. Kathryn Gleadle, Borderline Citizens. Women, Gender, and Political Culture in Britain, I8I5-I867, Oxford: Oxford University Press 2009, s. I7, https://doi.org/I0.587I/ bacad/9780197264492.00I.ooor. Se även Christina Florin \& Lars Kvarnström (red.), Kvinnor på gränsen till medborgarskap. Genus, politik och offentlighet 1800-1950, Stockholm: Bokförlaget Atlas 2002.

6. Anna Bohlin, "Kök till vildmark. Det kvinnliga medborgarskapets spatialitet i nordisk i840-talslitteratur", Alexandra Borg, Andreas Hedberg, Maria Karlsson, Jerry Määttä \& Åsa Warnqvist (red.), Konstellationer. Festskrift till Anna Williams, Hedemora: Gidlunds förlag 2017, s. 79-93; Anna Bohlin, "Female Citizenship in Scandinavian Literature in the 1840 ", Rethinking Scandinavia - CSS Publications Web Quarterly vol. 2, July 2018, http://www.css.lu.se/fileadmin/user_upload/CSS/ CSS_Quarterly/_2/RS_2_-_Anna_Bohlin_-_Female_Citizenship_in_Scandinavian_Literature_in_the_I840s.html (hämtad I5/8 20I8).

7. Exempelvis hade den spåkunniga kvinnan Vappo i Fredrika Runebergs Fru Catharina Boije och hennes döttrar (I858) med fördel kunnat ingå i undersökningen. Hennes "aningar" gäller dock individer, som visserligen i sin tur representerar nationen, men det kräver en mer omfattande analys än utrymmet i denna artikel medger. 
händelserna I74I-I743. ${ }^{8}$ Den andra delen framställer samma period som inre historia, som människors upplevelser - styrda av en häxa. I den historiska romansviten Fältskärns berättelser (I853-1867) behandlar den andra cykeln ingående I6oo-talets häxförföljelser och ställer en anklagad kvinna i centrum. Sara Wacklin skildrar mer näraliggande historia i Hundrade minnen från Österbotten (I844-I845). Till skillnad från de andra texter som behandlas här, är Wacklins verk inte skönlitteratur, utan snarare en samling litterärt bearbetade anekdoter från I80o-talets första hälft, där trolldomskunniga personer av båda könen förekommer. Magi spelar även en viktig roll i Fredrika Bremers samtidsromaner från 1840-talet och medborgarskap tematiseras i både En dagbok (1843), som utspelar sig i Stockholm, och I Dalarna (1845), som i nationalistisk anda presenterar detta ännu vilda och otillgängliga landskap. I C.J.L. Almqvists songe "Häxan i Konung Carls tid" (I849) förekommer möjligen Almqvists mest kända häxa, men fler finns i romanen Tre fruar i Småland (I842-I843), som liksom Bremers I Dalarna presenterar geografin kopplad till nationella dygder. ${ }^{9}$ Det handlar om trolldom som på olika sätt ges betydelse för nationsbygget.

Religiösa aspekter av nationalism har de senaste åren lyfts fram i allt större utsträckning, och i det avseendet utgör de nordiska nationalismerna under I80o-talet ett särfall. ${ }^{10}$ Förankringen av nationernas rötter $\mathrm{i}$ ett hedniskt förflutet innebar att 1800 -talets nationalismer måste förhålla sig till en konflikt mellan olika trossystem; det gäller särskilt de tänkare som likt Topelius, Bremer och Almqvist uppfattade

8. Hertiginnan af Finland kom vidare ut i en ny,omarbetad utgåva I88o. Analysen begränsas till bokutgåvan I85o, eftersom den var den mest spridda vid mitten av i80o-talet. Angående de betydande skillnaderna mellan följetongen och de olika utgåvorna, se Pia Forssell \& Matti Klinge,"Inledning”, Zacharias Topelius, Hertiginnan af Finland och andra historiska noveller, Zacharias Topelius Skrifter V, utg. Pia Forssell, Helsingfors: Svenska litteratursällskapet i Finland / Stockholm: Bokförlaget Atlantis 20I3, s. XII-XIX, XXXIII-XLII.

9. Anna Bohlin,"Den svenska I840-talsromanen som nationell kartografi", Samlaren I37, 2016, s. 58-86.

ıo. James C. Kennedy,"Religion, Nation and European Representations of the Past", Stefan Berger \& Chris Lorenz (eds.), The Contested Nation, Ethnicity, Class, Religion and Gender in National Histories, Basingstoke \& New York: Palgrave Macmillan 2008, s. I04-I34; Timothy Baycroft, "Introduction”, Timothy Baycroft \& David Hopkin (eds.), Folklore and Nationalism in Europe During the Long Nineteenth Century, Leiden \& Boston: Brill 20I2, s. 4 f., https://doi.org/Io.II63/97890042II834_002. 
nationen som ett steg i Guds plan med mänskligheten. ${ }^{11}$ Fornnordisk myt och folktro måste infogas i en kristen utvecklingstanke. Nationalismens troskonflikt tvingar med andra ord fram en komplicerad tidsaspekt som bör studeras.

Syftet är att undersöka hur häxan i de litterära framställningarna ges en ny funktion i nationens tjänst. Hur relateras trolldom till olika trossystem och hur implicerar det temporalitet? De nya nationernas subjekt var medborgaren, men hur förhåller sig detta upplysningsbegrepp till trolldom och idén om hedniska rötter? Vidare kommer genusaspekten att belysas: forskningen uppskattar att $75-85$ procent av de mellan 40 ooo och 60000 människor som dömdes för trolldom över hela Europa var kvinnor, och det nationalistiska återbruket av häxan sker i en tid när kvinnokroppar, Finlands mö och Moder Svea, blir symboliska representationer av nationen. En fjärde frågeställning gäller etnicitet, vilket ska ses mot bakgrund av det grundmurade rykte om trolldomskunnighet som sedan århundraden förknippades med samer och finnar. De nationalistiska projekten under I8oo-talets första hälft handlade om att skapa en enhet ur regional, klassmässig, språklig, etnisk mångfald. Därför finns anledning att studera hur föreställningen om trolldomens etniska koppling hanteras i visionen om nationen.

De politiska förutsättningarna var förvisso olika för Finland och Sverige efter I809. I Finland blev litteraturen med namn som Topelius och Runeberg en viktig del av nationsbygget. ${ }^{12}$ Samtidigt är det svårt

II. Pertti Anttonen,"Oral Traditions and the Making of the Finnish Nation", Timothy Baycroft \& David Hopkin (eds.), Folklore and Nationalism in Europe During the Long Nineteenth Century, Leiden \& Boston: Brill 20I2, s. 338-340, https://doi. org/Io.Ir63/97890042II834_or7; Klinge, Idyll och hot, s. 28, 256; Kurt Aspelin, "Det europeiska missnöjet". Sambällsanalys och historiespekulation. Studier i C.J. L. Almqvists forfattarskap åren kring I840, del I, Stockholm: Norstedt \& söners förlag 1979, s. II2-II5; Anders Burman, Politik i sak. C.J.L. Almqvists sambällstänkande I839-I85I, Stockholm/Stehag: Symposion 2005, s. I65; Anna Bohlin,"Fredrika Bremer's Concept of the Nation during Her American Journey", Ideas in History 7, 2013:I-2, s. $43-70$.

I2. Anttonen,"Oral Traditions and the Making of the Finnish Nation", s. 325-35o; Johan Wrede, Världen enligt Runeberg, En biografisk och idébistorisk studie, Helsingfors: Svenska litteratursällskapet i Finland / Stockholm: Atlantis 2005; Peter Aronsson, Narve Fulsås, Pertti Haapala \& Bernard Eric Jensen,"Nordic National Histories", Stefan Berger \& Chris Lorenz (eds.), The Contested Nation. Ethnicity, Class, Religion and Gender in National Histories, Basingstoke \& New York: Palgrave Macmillan 2008, s. 256-282. 
att överskatta Runebergs och Topelius betydelse även för den svenska nationalismen. ${ }^{13}$ Den historia som nu skulle tas i bruk för att forma dessa olika nationer hade under många århundraden utspelats inom ett gemensamt rike. Studiens transnationella angreppssätt motiveras av att den litterära marknaden i Finland och Sverige delvis var gemensam - denna litteratur var del av samma samtal, om än med ambitionen att skapa två olika nationer. ${ }^{14}$ Häxan i litteraturen är en iscensättning av det folkloristiska material som man, i syfte att legitimera nationen, börjat samla in ett par årtionden tidigare, en insamling som inte minst resulterade i publiceringen av Kalevala (1835). Pertti Anttonen understryker insamlingarnas ideologiska incitament:

Genom att omvandla tradition till arv, och genom att representationen av traditionen bygger på metonymi, har studiet av muntliga traditioner skapat 'nationella texter' författade av det av nationalismen alstrade 'folket', som hörs tala med 'nationens' röst. ${ }^{15}$

Folkets "röst" var en kraftfull ideologisk figur i i8oo-talets litteratur, och häxan blir ett av de språkrör som konstruerar skilda folk med utgångspunkt $\mathrm{i}$ transnationella magiska föreställningar.

För I8oo-talets människor var magi inte nödvändigtvis ett halvt bortglömt förflutet eller oskadliggjort i barnsagor: många uppfattade trolldom som ett verkligt hot. En kamp om tolkningsföreträde pågick. Artikeln tar därför ansats i en kort bakgrund om magiska föreställningar under finskt och svenskt I8oo-tal samt trolldomsprocessernas

I3. Se t.ex. Wrede, Världen enligt Runeberg, s. 337; Selma Lagerlöf, Zachris Topelius, Stockholm: Albert Bonniers förlag I920.

I4. Pia Forssell, Författaren, förläggarna och forskarna. J. L. Runeberg och utgioningsbistorien i Finland och Sverige, Helsingfors: Svenska litteratursällskapet i Finland 2009.

15. "By transforming tradition into heritage, and by metonymising tradition in the course of its representation, the study of oral traditions has created 'national texts' that are authored by the nationalistically conceived 'folk', who are heard to speak in the voice of 'the nation'.", Anttonen, "Oral Traditions and the Making of the Finnish Nation", s. 330 [Översättning till svenska: MJ]. Se även Joep Leerssen, "Oral Epic: The Nation Finds a Voice",Timothy Baycroft \& David Hopkin (eds.), Folklore and Nationalism in Europe During the Long Nineteenth Century, Leiden \& Boston: Brill 20I2, s. II-26, https://doi.org/Io.II63/97890042II834_003. 
historia. Analyserna av litteraturen avslutas med en sammanfattande diskussion om häxan som nationens röst.

\section{TROLLDOM}

År 1858 utbröt häxpanik i Gagnef socken i Dalarna. Nioåriga Anna i Myrholn klagade över att hon tillsammans med ett par andra barn hade blivit förd till Josefsdal, det lokala namnet på Blåkulla, av Mann-Anna från grannbyn. Innan trolldomsutbrottet var över hade 720 personer blivit indragna - ryktesspridningen var särskilt utbredd i kapellaget Mockfjärd, där 30 procent av hushållen var direkt berörda. ${ }^{16}$ Dessa händelser inträffade drygt ett decennium efter publiceringen av Bremers roman I Dalarna (1845). Romanen utspelar sig inte långt ifrån Gagnef, men Bremer avvisar huvudsakligen trolldom som vidskepelse. I en not anför hon ett fall ur samtiden som bevis på dalfolkets föregivet arkaiska fantasi: för att bota ett barn som hävdade att hen blivit förd till Blåkulla läste prästen högt ur en antik romersk författares verk, varpå barnet föll $\mathrm{i}$ djup sömn och därefter inte mer anfäktades av häxor. ${ }^{17}$ Som analysen kommer att visa får emellertid magi betydligt vidare implikationer i romanen.

I verklighetens Gagnef lät prästen Robert Blumenberg Anna stanna i prästgården under ett par veckor för att man skulle driva ut djävulen. Därefter blev prästgården bestormad av barn, de flesta i åldern 5-9 år, som vittnade om Blåkulla. Domkapitlet i Västerås tillsatte en kommission som utredde anklagelserna och förflyttade prästen för att man menade att han uppmuntrat vidskepelse. Historikern Kristina Tegler Jerselius, som studerat trolldomsutbrottet i Gagnef, inskärper att trolldom under 1800-talet inte bör uppfattas som ett marginellt fenomen. Häxanklagelser förekom i Sverige under hela 180o-talet; anledningen till att spåren i tillgängliga källor är relativt få, är med största sannolikhet att kyrkan tillämpade en tystnadsstrategi. Allmogens tro på trolldom skulle tigas ihjäl. ${ }^{18}$

16. Kristina Tegler Jerselius, Den stora häxdansen. Vidskepelse, väckelse och vetande $i$ Gagnef I858, Uppsala: Historiska institutionen vid Uppsala universitet 2003, s. I29.

I7. Fredrika Bremer, I Dalarna. Nya teckningar ur hvardagslifvet, del 7, Stockholm: L.J. Hjerta 1845 , s. $4 \mathrm{I}$ f.

I8. Tegler Jerselius, Den stora häxdansen, s. $301 \mathrm{f}$. 
Magiska föreställningar försvann inte bara för att domstolar upphörde att utdöma straff - avförtrollningen av världen är en betydligt mer komplex och utdragen historia. Den sista dödsdomen för trolldom i Europa utfärdades i Schweiz r782, men lokalbefolkningen fortsatte att ta saken i egna händer och utpekade häxor lynchades och brändes inne i många länder, däribland Frankrike och Ryssland, under hela I80o-talet ${ }^{19}$ Det mest kända offret är irländska Bridget Cleary, som år 1895 brändes av sin man och andra släktingar, eftersom mannen var övertygad om att älvorna tagit hans riktiga hustru och i stället lämnat en bortbyting, som måste skrämmas bort genom att hållas över eld. ${ }^{20}$ Det sista kända fallet av innebränning är från Polen så sent som år 1984. Anklagelser och misshandel förekom in på 1900-talet över stora delar av Europa, också i Norden. ${ }^{21}$ Dödsstraffet för trolldom avskaffades i Sverige och Finland år 1779 av Gustav III, som i motsats till exempelvis prästeståndet förlöjligade tron på djävulen. Det hindrade dock inte kungen från att tro på animalisk magnetism och spådomar. ${ }^{22}$ I Sverige antogs en ny strafflag år I864, som i linje med annan europeisk strafflagstiftning nu definierade "trolldom" som "bedrägeri". ${ }^{23}$

Diskussionen om djävulens väsen och förmåga att agera pågick under hela häxprocessernas historia. Redan på 1500-talet fanns motstånd mot reales-hypotesen - att häxsabbat inträffade på riktigt; många argumenterade för att det handlade om illusiones Diaboli, drömmar eller hallucinationer som likafullt härrörde från djävulen. ${ }^{24}$ De europeiska

19. Marijke Gijswijt-Hofstra,"Witchcraft after the Witch-Trials", Bengt Ankarloo \& Stuart Clark (eds.), Witchcraft and Magic in Europe. The Eighteenth and Nineteenth Centuries, Philadelphia: University of Pennsylvania Press 1999, s. 95-189.

20. Angela Bourke, The Burning of Bridget Cleary. A True Story, London: Pimlico 2006.

2I. Gijswijt-Hofstra,"Witchcraft after the Witch-Trials", s. I5I-I59.

22. Linda Oja, Varken Gud eller natur. Synen på magi i I60o- och I70o-talets Sverige, Stockholm/Stehag: Symposion I999, s. I0I, $280 \mathrm{f}$.

23. Ibid., s. Ior f.; Brian P. Levack, "The Decline and End of Witchcraft Prosecutions", Bengt Ankarloo \& Stuart Clark (eds.), Witchcraft and Magic in Europe. The Eighteenth and Nineteenth Centuries, Philadelphia: University of Pennsylvania Press 1999, s. 74-82.

24. Virginia Krause, Witchcraft, Demonology, and Confession in Early Modern France, Cambridge \& New York: Cambridge University Press 2015, s. 19, https://doi.org/Io.IoI7/ cbo978Ir39696685; Göran Malmstedt, "Onda drömmar. Om dröm och verklighet i bohuslänska trolldomsmål r669-ı672", M. Cavallin Aijmer, G. Malmstedt, K. Nyberg, A. von Schéele \& M. Weikert (red.), Arbete, kultur, politik. En vänbok till Lennart K. Persson, Göteborg: Historiska institutionen i Göteborg 2007, s. 63 f. 
häxprocesserna är ett högst diversifierat fenomen både i termer av tid, straffsatser, kön, och anklagelsernas innehåll. När häxpaniken drabbade Sverige och Finland under andra halvan av i6oo-talet var den redan över på kontinenten. Även inom samma lagskipningsområde finns stora regionala skillnader. De stora häxprocesserna åren r668-ı676, då sammanlagt 240 människor avrättades, är huvudsakligen lokaliserade till norra och mellersta Sverige: Dalarna, Norrland, Värmland och Stockholm. Visserligen avkunnades många dödsdomar i trolldomsmål i Bohuslän och på Åland, men generellt utdömdes mildare straff i södra Sverige och i Finland. ${ }^{25}$ Forskningen räknar med tre huvudkategorier av trolldom. Vit magi syftar till att bota och hjälpa (ofta fanns delade meningar mellan lagens företrädare och de anklagade om huruvida vit magi skulle betraktas som straffbart), medan maleficium är termen för magisk skadegörelse. Pakt med djävulen utgör en egen, tredje kategori. ${ }^{26}$ Trots att majoriteten av de anklagade var kvinnor fanns en variation i könsfördelningen: på Island anklagades nästan uteslutande män för trolldom (ca 90 \%) och även Estland (60 \%) och Finland (49 \%) uppvisar en ovanligt hög andel män, vilket också avspeglas i den finländska I80o-talslitteraturen. ${ }^{27}$ Andelen kvinnor tenderade att vara större då anklagelserna gällde häxsabbat, förmodligen eftersom tortyr användes oftare i dessa mål för att pressa kvinnor att peka ut varandra. ${ }^{28}$

Etnologen Laura Stark har studerat magiska föreställningar i finskspråkigt material i Finska litteratursällskapets rika folkminnesarkiv. Magiska riter och besvärjelser användes i vissa trakter in på I940-talet för att bota sjukdomar och skada fiender. ${ }^{29}$ De systematiska etnografiska uppteckningarna av bland annat magiska föreställningar

25. Raisa Maria Toivo, Witchcraft and Gender in Early Modern Society. Finland and the Wider European Experience, Aldershot \& Burlington: Ashgate 2008, s. II2; Oja, Varken Gud eller natur, s. 164, 210.

26. Oja, Varken Gud eller natur, s. 22.

27. Toivo, Witchcraft and Gender, s. I29. Se även Raisa Maria Toivo,"Male Witches and Masculinity in Early Modern Finnish Witchcraft Trials", Marianna G. Muravyeva \& Raisa Maria Toivo (eds.), Gender in Late Medieval and Early Modern Europe, London \& New York: Routledge 2013, s. I37-I52.

28. Toivo, Witchcraft and Gender, s. I30; Liv Helene Willumsen, Witches of the North: Scotland and Finnmark, Leiden \& Boston: Brill 2013.

29. Laura Stark, The Magical Self. Body, Society and the Supernatural in Early Modern Rural Finland, Helsinki: Suomalainen tiedeakatemia 2006, s. 47. 
startade på I830-talet, men tog fart på allvar under I870-talet, när folkminnen blev en folkrörelse och insamlingen en patriotisk dygd. ${ }^{30}$ Litteraturen i urvalet befinner sig med andra ord i inledningsskedet: den är inspirerad av Kalevala och annat tidigt folkminnesmaterial i Finland och Sverige, men publicerad innan insamlingen blev allmän. Det finns anledning att anta att de litterära verken bidrog till intresset för folktro, och man kan också konstatera att de ingick i kampen om tolkningsföreträde. Stark har funnit exempel på att samlingar med magiska besvärjelser förekom under 1840-talet, samtidigt som de flesta verken i urvalet gavs ut, och tietäjä (termen för en person med den största magiska kompetensen) var fortfarande en verksam figur på finska landsbygden vid den tid de här behandlade verken skrevs. ${ }^{31}$

Fallet Blumenberg i Dalarna I858 visar på en aspekt som komplicerar relationen mellan magi och det moderna subjektet. Tegler Jerselius lyfter fram att Blumenbergs bakgrund i läseri och nykterhetsrörelse ledde till att han omtolkade Gagnefbornas magiska föreställningar i enlighet med en väckelsekristen världsbild. Barnens djävulsanfäktelser uppfattades som straff för föräldrarnas syndiga leverne och en väckelse uppstod också som en direkt följd av häxanklagelserna. ${ }^{32}$ Väckelserörelsernas betoning av det individuella gudsförhållandet och den inre övertygelsen brukar förstås som ett viktigt led i framväxten av det moderna subjektet, och samtidigt har forskningen pekat på att väckelsen delade magins dualistiska världsbild. Tom Ericsson och Börje Harnesk understryker i sin studie av läseriet i övre Norrland att kampen mellan det onda och det goda präglade ortodox lutherdom likaväl som folklig trolldom. Under inflytande av upplysningen förändrades dock gudsbilden och förståelsen av Satans makt: den rationalistiska neologin kom att dominera bland prästerskapet från slutet av i7oo-talet, och synsättet präglades av en optimistisk människosyn och en monistisk världsbild. Det resulterade i Sverige bland annat i den Lindblomska

3o. Ibid., s. $\mathrm{II} 6 \mathrm{f}$.

3I. Ibid., s. 75. Se även Toivo, "Male Witches and Masculinity", s. I42 f.; Raisa Maria Toivo, "Gender, Sex and Cultures of Trouble in Witchcraft Studies: European Historiography with Special Reference to Finland", Marko Nenonen \& Raisa Maria Toivo (eds.), Writing Witch-Hunt Histories. Challenging the Paradigm, Leiden \& Boston: Brill 2014, s. IO2-IO5, https://doi.org/Io.II63/97890042579I7.

32. Tegler Jerselius, Den stora häxdansen, s. 77, 229-263. 
katekesen I8Io, som varnade för vidskepelse i betydelsen människor som utger sig för att kunna trolla. Läsarna, däremot, kämpade för att få behålla exorcism i samband med dop och den gamla Svebilii katekes (på svenska i689, på finska I746), som varnade för skogsrån och tomtar. Katekesens varningar togs ofta som intäkt för att dessa magiska väsen existerade. Folktron, skriver Ericsson och Harnesk, "var en komplex sammansmältning av ortodox kristendom och folklig magi", som inte låter sig uppdelas i olika trossystem. ${ }^{33}$

Som Brian P. Levack noterar har häxprocessernas uppkomst ägnats större intresse än deras tillbakagång. Den slentrianmässiga förklaringen att upplysningen rensade bort vidskepelse håller inte, eftersom häxjakterna avstannade på många håll i Europa långt innan upplysningens idéer vann mark. Levack visar att många av de jurister som satte stopp för rättegångarna inte nödvändigtvis betvivlade själva brottets existens, men däremot möjligheten att leda det i bevis. Risken att döma oskyldiga var alltför överhängande. ${ }^{34}$ Upplysningens seger över vidskepelse är upplysningens egen myt. I Frankrike förde upplysningsfilosoferna ett "korståg" mot magi, och redan i I70o-talets brittiska press etableras bilden av häxan som en stackars fattig, gammal kvinna, som faller offer för okunnighet och barbari. ${ }^{35}$ Roy Porter påpekar att häxan, som tidigare representerat konflikten mellan Gud och Satan, nu i stället kom att representera en konflikt mellan civiliserad bildning och allmogens obildning. ${ }^{36}$ Den liberala pressens kampanj mot vidskepelse pågick som bäst under samma tid som verken $\mathrm{i}$ urvalet publicerades. Stark citerar Turun Lehtis redaktör J.F. Hagfors, som så sent som 1889 klagade över att folket levde med föreställningar från hednisk tid och krävde att de skulle upplysas genom utbyggnad

33. Tom Ericsson \& Börje Harnesk, Präster, predikare och profeter. Läseriet i övre Norrland I800-I850, Gideå: Vildros 1994, s. 93-I03. Se även Raisa Maria Toivo, Faith and Magic in Early Modern Finland, Basingstoke \& New York: Palgrave Macmillan 2016, s. 9-15, https://doi.org/10.1057/978Ir37547279; Stark, The Magical Self, s. 230-233; Oja, Varken Gud eller natur, s. 3I, 65.

34. Levack, "The Decline and End of Witchcraft Prosecutions", s. I-93. Se även Oja, Varken Gud eller natur, s. 35, 93.

35. Roy Porter, "Witchcraft and Magic in Enlightenment, Romantic and Liberal Thought", Bengt Ankarloo \& Stuart Clark (eds.), Witchcraft and Magic in Europe. The Eighteenth and Nineteenth Centuries, Philadelphia: University of Pennsylvania Press I999, s. 207-236.

36. Ibid., s. I96. 
av skolväsendet. ${ }^{37}$ Prästen Blumenberg och Gagnefborna fick I858 likaså löpa gatlopp i pressen, som förfasade sig över denna "dystra vidskepelse". ${ }^{38}$ I pressens rapporter från kommissionens förhör gjorde man sig lustig över barnen i röda hättor och gula koltar, som ”öppet och käckt" vittnat om djävulspakt och häxsabbat. ${ }^{39}$ Häxanklagelser blev underhållning. Hos Bremer, Wacklin, Almqvist och Topelius får emellertid trolldom en betydligt mer komplex betydelse för nationsbygge, tid och medborgarskap.

\section{BREMERS HEDNISKA RÖSTER: \\ KVINNLIGT MEDBORGARSKAP}

Bremers häxor ges en bärande relation till medborgarskap. Romanen I Dalarna är genomsyrad av referenser till Eddalitteraturen, och flera av folktrons magiska väsen, som näcken, bergakungen och sjörået, aktualiseras i förbigående. Romanens huvudperson, tonårsflickan Siri, kallas omedelbart skämtsamt för "troll" och jämförs med älvdrottningen. Mycket riktigt uppvisar hon starkt motstånd mot disciplin och vägrar gå i kyrkan. Hennes intuitiva band till naturen låter henne höra och se saker som andra inte kan förnimma, och det gör henne också till en kärleksfull vårdare av barn och djur. ${ }^{40}$ Under berättelsens gång etableras Siri som naturens inre ande - landskapet uppfattas

37. Stark, The Magical Self, s. 35; J.F. Hagfors, "Waloa Kansallemme!", Turun Lehti 27/4 I889 $\mathrm{nr} 5$ \%; J.F. Hagfors, "Taikausko", Turun Lehti Io/3 I887 nr 28. Se även Bourke, The Burning of Bridget Cleary, s. I2I-I25.

38. Tegler Jerselius, Den stora häxdansen, s. III.

39. Ibid., s. 267. Se även Emil Herlenius, "Blåkullafärder i det nittonde århundradet", Svenska landsmål och svenskt folkliv årg. I7, utg. Landsmålsföreningarna i Uppsala, Helsingfors och Lund I9I2, s. 30.

40. Carina Burman noterar Siris förbund med naturen och Bremers intresse för det övernaturliga i Carina Burman, "Knytt och oknytt, djuriskt och mänskligt hos Fredrika Bremer", Anita Widén (red.), Fredrika Bremer - föregångare och förebild, Hedemora: Gidlunds förlag 2005, s. 65 f. Se även Carina Burman, Bremer. En biografi, Stockholm: Albert Bonniers förlag 200I, s. 245-249. Om Bremers egen resa i Dalarna, planerad tillsammans med prof. Christian Erik Fahlcrantz, som senare i egenskap av biskop i Västerås skulle tillsätta trolldomskommissionen i Gagnef, se Gunnel Furuland, "Författare som resenärer och resenärer som författare. Fredrika Bremer och H.C. Andersen i Dalarna”, Gunnel \& Lars Furuland, Resenärer i Dalarna - från Carl von Linné till Göran Palm, Mora: Stiftelsen Bonäs Bygdegård 2007, s. 19-49. 
som "en bild" av henne; hon beskrivs som en "Siren" vid ättehögen, befolkad av "hög-folket", och spelar toner av "Dalarnas lif". ${ }^{41}$ Den enda magi hon möjligtvis utövar är vit: hon läser en besvärjelse mot "Näcke-bett" över vetenskapsmannen Olof, vilket visserligen inte hjälper mot smärtan i handen, men han blir "liksom fasttrollad" av hennes ögon. ${ }^{42}$ Det föranleder en utläggning om blickens magiska kraft i folktro och forntid, men i romanen omtolkas blickens magi i en psykologiserande referensram. Trolldomens betydelse i romanen förstärks dock genom att Siri själv identifierar sig med de 47 personer som brändes som häxor i Dalarna mellan åren I668 och I673. Hon uppsöker platsen för bålen och ger en detaljerad skildring av Blåkulla. ${ }^{43}$

Berättelser om Blåkullaresor, den specifikt svenska varianten av häxsabbat, har uppvisat förvånansvärd stabilitet från ı6oo-talet fram till r8oo-talet; de förekom på Åland, men demonologiska inslag var annars ovanliga i finska trolldomsprocesser. ${ }^{44}$ Barnvittnen brukar framhållas som ett annat särdrag för svenska (och spanska) rättegångar, men de saknades i Bohuslän. ${ }^{45}$ Inte ens berättelser om sex med djävulen, ett standardelement i häxsabbaten, förekom överallt; exempelvis saknas de i norska Finnmarken och även i fallet med barnen i Gagnef I858. ${ }^{46}$ I samtliga texter i urvalet florerar rykten om djävulspakter, men de visar sig alla vara ogrundade. Religionsvetaren Per Faxneld har studerat Satan som symbol för den förtrycktas revolt i socialistiska och feministiska rörelser mot slutet av I8oo-talet och lyfter även fram motivet i europeisk, romantisk litteratur. ${ }^{47} \mathrm{I}$ den nationsbyggande

4I. Bremer, I Dalarna, s. III-II3. Ang. nationalism och landskap, se Bohlin, ”Den svenska i840-talsromanen som nationell kartograf".

42. Bremer, I Dalarna, s. I76 f.

43. Ibid., s. 36-44.

44. Toivo, Witchcraft and Gender, s. 60 f. Per-Anders Östling, Blåkulla, magi och trolldomsprocesser. En folkloristisk studie av folkliga trosföreställningar och av trolldomsprocesserna inom Svea Hovrätts jurisdiktion 1597-I720, Uppsala: Etnologiska avdelningen, Uppsala universitet 2002, s. 204.

45. Bengt Ankarloo, Satans raseri. En sannfärdig berättelse om det stora häxoväsendet $i$ Sverige och omgivande länder, Stockholm: Ordfront 2007, s. I78; Malmstedt,"Onda drömmar", s. 48.

46. Willumsen, Witches of the North, s. 254; Tegler Jerselius, Den stora bäxdansen, s. I9I.

47. Per Faxneld, Satanic Feminism. Lucifer as the Liberator of Woman in Nineteenth-Century Culture, Stockholm: Molin 2014, https://doi.org/Io.I093/oso/ 9780190664473.001.0001. 
finländska och svenska litteraturen vid mitten av I8oo-talet hålls dock Satan på distans. Siri i Bremers I Dalarna vill visserligen "bra gerna se satan", men inte ha något närmare samröre med honom. ${ }^{48}$ Bremer har hämtat uppgifterna om Blåkulla ur Handlingar om trolldoms-wäsendet i Dalarne åren I668-1673, utgiven av C. G. Kröningssvärd år I821 och aktuell i en nyutgåva just 1845 . En sammanfattning av dessa svenska rättegångsprotokoll översattes till många språk redan på i67o-talet och såldes som skillingtryck på mässan i Frankfurt - den fick senare också betydelse för häxprocesserna i Salem, New England på r69o-talet. ${ }^{49}$

I I80o-talets nationalistiska litteratur togs protokollen i bruk för diametralt motsatt ändamål: häxan skulle inte längre brännas på bål, utan ge folket röst. Liksom i många av det svenska I8oo-talets nationalistiska romaner hyllas Gustav Vasa sida upp och sida ner i Bremers roman, främst av sin namne och representant för rikets överhet, riksdagsmannen och prosten professor Gustaf Nordevall. Gustav Vasa fungerar som emblemet för nationens frihet. Kungen får dock konkurrens av häxan. Siris vildhet kopplats ständigt till frihet i romanen - häxan blir emblemet för den individens frihet som den liberala demokratin utlovade. Signifikativt nog formuleras visionen om nationen inte av riksdagsmannen, Siris styvfar, utan av hennes köttslige far, en genial man som förbrutit sig mot riket och därmed förverkat sin egen framtid. Framtiden, Siri, överlämnas i styvfaderns händer - till kyrka och stat - av den biologiske fadern. Han får i slutet av romanen konstruera en försoning i nationalismens religiösa konflikt, förbinda dess tre tidsplan och klargöra kopplingen mellan magi och medborgarskap.

Vid nedgången till underjorden, närmare bestämt Falu koppargruva, riktas faderns sista ord till Siri i ett inspirerat tal om "den lära, som dina fosterländska sägner och sånger förkunna, om naturens, om kreaturens lif, om menniskans kallelse". ${ }^{50}$ Insikten om människans kallelse i nutiden ska sökas i forntidens litteratur, där"naturens sakta anderöster" talar. "Hör! de sucka efter förlossning, efter ett friare,

\footnotetext{
48. Bremer, I Dalarna, s. 43 .

49. Ankarloo, Satans raseri, s. 205; Bengt Ankarloo, "Älvdalen - Mora och de stora europeiska häxförföljelserna”, Andreas Östborn (red.), Dalarnas häxprocesser, Mora: Stiftelsen Bonäs Bygdegård 2000, s. 5-20.

5o. Bremer, I Dalarna, s. 340.
} 
skönare lif, och de kalla på menniskan att befria dem [...].” ${ }^{51}$ I Bremers nationalistiska myt ska naturens hedniska röster förlossas till evigt liv i kristendomens ljus, och denna sammansmältning av två trossystem får omedelbar betydelse för individens medborgarskap och nationens framtid. Nordens långsamma modernisering och kvardröjande magiska föreställningar blir en tillgång för den moderna medborgarstatens framtid i den nya generationen:

Väl dig att du blef född i ett land, der djupa anderöster ännu genomljuda lifvet. Mitt barn! Blif en välsignelse för din fosterjord! Der stå ättehögarne, som gömma dina förfäders ben, der äro urbergen, källorna, som bevara sägnerne från äldsta tider, då menniskoanden i sina aningar var lika djup, som nu, i sina klaraste begrepp. I denna natur blev du född; der skall du lefva och verka. ${ }^{52}$

I den fornnordiska religionen finns en aning om den sanning som kristendomen klargör och formulerar som trossatser - denna hegelianska historieuppfattning delade Bremer med många samtida. I Bremers författarskap ger den utslag i gestaltningen av häxan som en kanal ner i ett hedniskt ursprung med uppdrag att vitalisera samhället; det är en kongenial gestaltning av nationalismens tredimensionella temporalitet, fantasin om forntiden formar samtiden och framtiden.

Den nationsgrundande litteraturen i denna roman är Eddorna, men Bremer citerar också ur "den finska nationaldikten, Kalevala”, beskrivningen av hur Lemminkäinens mor vaggar och därmed helar sin son:"Hvem har lidit och stridit på jorden och förstår icke meningen, sanningen i denna saga?" ${ }^{53}$ Kalevalas visdom är här en symbolisk sanning, men i romanen En dagbok antyds att Kalevala också förmedlar verksam magi. En dagbok är den roman i författarskapet som före Hertha (I856) tydligast tematiserar kvinnligt medborgarskap, och här understryks kopplingen till magi. Huvudpersonen Sofia Adelan är, liksom Bremer själv, myndig efter ansökan hos kungen och född i

5I. Ibid.

52. Ibid., s. 34I.

53. Ibid., s. 62. 
"trollkonsternas hembygd, Finland" ${ }^{54}$ Hon är dessutom uppvuxen i finsk natur, behärskar finska, hyllar "det finska nationalsinnet", läser "min landsmans, Runebergs, lilla sköna skaldestycke 'Julaftonen", antyder viss magisk kunskap och är upplärd av en spåkvinna. ${ }^{55}$ Detta finska och magiska ursprung borgar för Sofias frihetsideal och framställs som orsak till hennes demokratiska övertygelse.

En verklig häxa med kraftfullt utseende och "stora, underliga" ögon förekommer i En dagbok, men hon studerar Bibeln, hävdar att oraklen numera flyttat in i människosjälen och uppmanar liksom nornorna i Hertha: "Följ den inre rösten!"”6 Begrepp som "förtrollning" och "trollmakt" fungerar i romanen som kod för makt över sitt eget och andra människors sinnen. Denna makt över andra framställs som ett potentiellt problem i det liberala samhällssystem där medborgaren ges ansvar att råda inte bara över sin egen person utan också över nationen. Trolldom har dock inte enbart en överförd betydelse; länken till en magisk föreställningsvärld bevaras. Sofia känner "ursprungsord" ur Kalevala och förklarar ordens makt över omgivningen: när "tingens $u r$-väsen [...] besvärjas i sådana ord, måste de svara, måste de lyda". ${ }^{57}$ Själv har Sofia ett inre "hedniskt troll", som visserligen blivit mer "kristnadt" med åren, men hon har fortfarande "makt att lösa och binda andras andar, - ursprungsord röra sig i mitt inre" ${ }^{58}$ Romanen slutar med att det hedniska trollet, kristen försoning och medborgarinnans insats för nationen sammanfaller i "lifvets ursprungsord" - kärlek ${ }^{59}$ Hos Bremer öppnar naturens hedniska röster, genom häxan, för kvinnors samhällsbärande insats som fria medborgare.

54. Fredrika Bremer, En dagbok, utg. Maria Wahlström, Stockholm: Svenska Vitterhetssamfundet 2009, s. I7. Om kvinnligt medborgarskap och nation hos Bremer, se Bohlin, "Kök till vildmark".

55. Bremer, En dagbok, s. I7, 56, IO2. Kommentaren till den textkritiska utgåvan uppger angående "Julaftonen": "här avses sannolikt Julqvällen, en dikt i tre sånger från r84I". Maria Wahlström, "Ord- och sakförklaringar", Fredrika Bremer, En dagbok, utg. Maria Wahlström, Stockholm: Svenska Vitterhetssamfundet 2009, s. 215. Carina Burman lyfter fram Sofias trolldomsmakt i Burman, "Knytt och oknytt", s. 67 f. samt Bremer. En biografi, s. $233 \mathrm{f}$.

56. Bremer, En dagbok, s. 93 f.

57. Ibid., s. 48 .

58. Ibid., s. I4I.

59. Ibid., s. I95. 
Hos Sara Wacklin är magin fullkomligt verkningslös. Trolldomens funktion i Hundrade minnen från Österbotten är negativ: ett omvänt bevis på att Finland är modernt. Till skillnad från de övriga författarna i urvalet nämner Wacklin inte ens föreställningen om finnarnas särskilda koppling till magi, men den framgår indirekt som något att ta avstånd ifrån. Anekdotsamlingen inskärper bilden av Österbotten som befolkat av rationella medborgare med ambition och förmåga att sprida kunskap och välstånd i nationen.

Spänningen mellan den liberala pressens upplysningskampanj å ena sidan och det växande etnografiska intresset för att bevara folkkultur å den andra var också en temporal konflikt. Upplysningen hade enbart en temporal riktning: framtid. Överklassen blev"modern" genom att avskilja sig från "det gamla"; med Porters formulering avvisades magin av "moderniseringsivrare som otåligt ville begrava det förflutna och bygga upp en bättre framtid". ${ }^{60}$ Det moderna upplysningsbegreppet "medborgaren" vann popularitet även i rojalistiska kretsar, men kopplades fortfarande ihop med framstegstanken genom strävan att lösgöra sig från det förflutnas dunkla okunnighet. ${ }^{61}$ Denna föreställning ekar i I8oo-talslitteraturen, med olika styrka i olika verk. Mot detta står folket som subjekt för den nationalistiska etnografin, som tvärtom avser att göra kulturella föreställningar ur det förflutna bestämmande för såväl samtid som framtid. Ambivalensen mellan beundran och distans hos insamlarna av folkminnen, och mellan stolthet och skam hos deras informanter, har lyfts fram av flera forskare. ${ }^{62}$ Tegler Jerselius undersöker hur prästen Blumenberg efter I858 försökte återupprätta sitt anseende genom att inta forskarens mer distanserade hållning och skicka in dialekt- och folktrouppteckningar till Föreningen för Nerikes folkspråk och fornminnen, den första föreningen i sitt slag

6o. "modernizers anxious to bury the past and to build a better future". Porter,"Witchcraft and Magic", s. I93 [Översättning till svenska: MJ].

6r. Mikael Alm, Kungsord i elfte timmen. Språk och självbild $i$ det gustavianska enväldets legitimitetskamp I772-I809, Stockholm: Atlantis 2002, s. II6-I39; Jakob Christensson, Lyckoriket. Studier i svensk upplysning, Stockholm: Atlantis I996, s. I26-I64.

62. Se t.ex. Stark, The Magical Self, s. I34-I45; Levack, "The Decline and End of Witchcraft Prosecutions"; Ericsson \& Harnesk, Präster, predikare och profeter, s. 99. 
i Sverige, grundad $1856 .{ }^{63}$ Trolldom var dels det paradigmatiska exemplet på den moderna nationens motsats, dels dess konstituerande kärna. Wacklin ansluter sig dock förbehållslöst till pressens liberala kampanj mot vidskepelse.

De kunskapsgåvor till nationen som Wacklins goda medborgare skänker, bestod emellertid $i$ vissa fall $i$ att samla in runosånger med ambitionen att bevara precis de magiska föreställningar Wacklin vill förpassa till glömska. Faktum är att hela verket avslutas med en nationalistisk fanfar till M.A. Castréns och Elias Lönnrots ära:

$[\mathrm{P}]$ ris vare de värdige fosterlandsmän, som uppelda sina landsmäns håg för den glömda kantele och Finlands inhemska skaldekonst, hvilken ur sin gamla rot i den rika naturen snart skall åter uppblomstra, gynnad af en mild öfverhet! Wäinämöinen skall sålunda ännu stolt kunna nedblicka på kommande slägten, och alla urskogens invånare skola lyssna och sjelfva bergen genljudande darra af förtjusning vid den gamles harposlag och de glada, tacksamma lofsånger, som han egnar dem af Suomis söner, hvilka återlifvat det Finska nationallynnet. ${ }^{64}$

"Nationallynnet" ska förankras i urtiden och Väinämöinen ska vaka över framtiden tack vare vetenskapliga insatser i nutiden. Nationalismens tredimensionella temporalitet ligger fast: forntiden förväntas forma en samtid, för att ge utdelning i en lycklig framtid. Det är dock värt att notera att det är Kalevalas "skaldekonst" som betonas: runosången är "heliga qvarlefvor af [folkets] äldsta litteratur", men ingen visdom. ${ }^{65}$ Forskarnas kunskaper "om det $\mathrm{i}$ alla tider så märkvärdiga Finska folkets forntid och ursprung" kommer "ifrån Lappmarkernas mörker [och ger] ljus för fosterlandet" ${ }^{66}$ Magin går dock förlorad på vägen.

I kapitlet"Julin och Trollkarlen" ställs magin och medborgarskapet i direkt motsättning till varandra. Den vida berömde och fruktade tietäjän från Kuusamo Lappmark "var af en kolossal gestalt, hade små

63. Tegler Jerselius, Den stora häxdansen, s. 273-298.

64. Sara Wacklin, Hundrade minnen från Österbotten, del I-III, Stockholm: L.J. Hjerta I844-I845, s. III:I78.

65. Ibid.

66. Ibid., s. III:I77. 
blixtrande ögon" samt var"klädd i Lappdrägt med mudd och vantar" ${ }^{67}$ Hans kraftfulla förmågor inbegriper bland annat att uppväcka döda och framkalla vålnader, och han söker upp vetenskapsmannen Johan Julin - en föredömlig medborgare i Wacklins framställning - "som vågade i undergörande kraft och kunskap mäta sig med honom". ${ }^{68}$ Julin sätter honom dock på plats med hjälp av sin "elektricitets-machin". Allt trollkarlen rör vid ger elektriska stötar och han tvingas erkänna sin underlägsenhet - "nog ser jag nu, att ni är en större hexmästare än jag" - och kapitlet avslutas med bekännelsen att han i själva verket helt saknar förmåga att "göra underverk och öfvernaturliga saker". ${ }^{69}$ Vittnesmål om en vålnad som uppstiger ur graven rationaliseras också i en annan historia, där spöket visar sig vara en vitklädd flicka som sörjer vid sin välgörares grav. ${ }^{70}$

Visserligen framställs tietäjän $\mathrm{i}$ berättelsen som same, men det betyder inte att Wacklin prisger samerna åt trolldomens etniska kopplingar. Tvärtom framhålls samernas delaktighet $i$ insamlingen av djur, växter och mineraler till Julins naturaliekabinett, hans viktigaste medborgerliga bedrift." Sjelfva Fjell-Lapparne [...] förskaffade honom stora tillökningar" och deras bidrag gjorde bland annat insektssamlingen till "den dyrbaraste, i anseende till mängden af föga bekanta arter ifrån de Lappska, vidlyftiga ödemarkerna". ${ }^{71}$ Samernas insatser är avgörande för forskningen och därmed för nationens upplysning.

En av alla de ämbetsmän i staten som befolkar Wacklins minnen är borgmästare Timbom och även han konfronteras med trolldom. Hans hustru vill återvinna sin forna skönhet och mannens kärlek med hjälp av Noituri-Anna:"Hon var en jättelik qvinna, med en förfärligt bred mun, beväpnad med tvenne hvita rader af tänder, hvilka afbeto en spik med samma lätthet, som en ung skönhet en trådsända."72 Starka tänder var ett viktigt kännetecken på en trollkunnig person och att bita av järn visade den magiska makten över metallen. ${ }^{73}$ Den

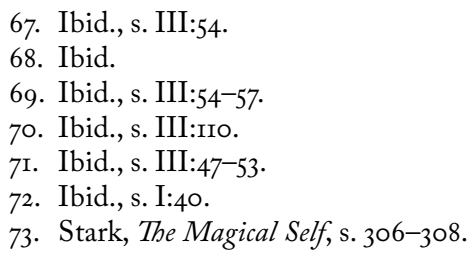


rit som beskrivs i Wacklins berättelse består i att herrskapet, iklädda sina gamla brudkläder, infinner sig på kyrkogården på natten, där Noituri-Anna ska utföra en bakvänd vigsel. Scenen på kyrkogården har drag av skräckromantik, den utgör "en pittoresk tafla": "det glesa, stripiga håret fladdrade kring [Noituri-Annas] förvridna anletsdrag, och de vilda ögonen stirrade hotande omkring sig, medan de snöhvita tänderna framskimrade ur den fradgande munnen”. ${ }^{74}$ Framför allt är dock anekdoten ett groteskt skämt. Wacklin driver hejdlöst med den urvuxna brudstassen, den berusade häxan och borgmästarens raseri över ovälkommen publik. Magin ger inte heller önskat resultat utan får en helt motsatt effekt. Borgmästaren, som tidigare gjort sin hustru till viljes i allt, förälskar sig i stället i en ung flicka.

Wacklin förlöjligar trolldom, magins företrädare förödmjukas och uppvisas som bedragare i enlighet med den syn som ligger bakom förändringen i brottsbenämningen till bedrägeri. Det enda som har en förtrollande effekt i Hundrade minnen från Österbotten är naturens skönhet och djävulen nämns endast vid ett tillfälle; den kvinna som var orsak till Uleåborgs brand 1822 bekänner på sin dödsbädd att"den onde hade ingifvit henne den föresatsen att bränna staden". ${ }^{75}$ Wacklin är välinformerad om de trolldomskunniga personernas magiska uppgifter och uppträdande - de är föremål för ett etnografiskt intresse - men magi rymmer ingen som helst sanning och ställs i direkt motsats till medborgarnas rationella agerande. Husbondeväldets patriarkala förtryck av kvinnor är något Wacklin ständigt återkommer till genom hela verket, men nyckeln till kvinnligt medborgarskap är privat inkomst snarare än hednisk visdom. ${ }^{76}$ Samtidigt är trolldomen fortfarande en del av nationens framgångssaga, den ger fortfarande röst åt nationens historia såsom ett övervunnet stadium i ett upplysningens optimistiska utvecklingsschema.

74. Wacklin, Hundrade minnen, s. I:42 f.

75. Ibid., s. III:III, I38.

76. Om kvinnligt medborgarskap hos Wacklin, se Bohlin, "Kök till vildmark". 


\section{AlMQVistS H ÄXOR: DEN SVENSKA FATTIGDOMEN}

Trolldom i Almqvists författarskap är till skillnad från i de tidigare nämnda författarnas verk ett hot mot överheten just för att den fungerar, åtminstone i hans songe nr XIV, "Häxan i Konung Carls tid":

Gumman, hon tog hvita stickor af furu.

Men sina stickor satte hon i en mur.

Sakta hon steg till muren och ur stickorna

darrhändt mjölkade hon åt barnena små. ${ }^{77}$

Tjuvmjölkning var en vanlig trolldomsanklagelse och kunde enligt folktron utföras antingen med hjälp av magiska väsen, så kallade "bäror", eller, som i Almqvists fall, med pinnar. ${ }^{78}$ Almqvists ärende är dock inte folklore utan fattigdom. Texten fortsätter:

Men utur rika Prestens ko var den söta mjölken.Barnena fingo stå vid Modrens bål. ${ }^{79}$

Häxan är här den goda modern som tvingas begå brott för att nära sina barn, men hennes handfasta fördelningspolitik straffar sig. Samhällets orättfärdiga hierarkier ger den som lever i överflöd rätt, mot den nödställda. Det är häxans budskap.

Framväxten av den starka staten under I6oo-talet har ofta framhållits som en viktig förklaring till häxprocesserna: kontrollen ökade genom att skatteuppbörden blev bättre organiserad och domstolsväsendet byggdes ut. Förbund med djävulen, att liera sig med fienden, innebar förräderi inte bara mot Gud, utan också mot konungen, lutherdomens förkämpe. ${ }^{80}$ Den starka staten framhålls emellertid också som en förklaring till avförtrollningen av världen; individen disciplineras av skolväsende och boklig bildning, samt av den kapitalistiska ekonomins behov av rörlig arbetskraft, vilket upplöste hushållsekonomins seder

77. C.J.L. Almqvist, Songe nr XIV,"Häxan i Konung Carls tid", Törnrosens bok Imperial Octav Upplaga II, Stockholm: P.A. Norstedt \& söner I849, s. I83 f.

78. Oja, Varken Gud eller natur, s. I7o.

79. Almqvist, Songe nr XIV, "Häxan i Konung Carls tid", s. I84.

8o. Oja, Varken Gud eller natur, s. 26, 69 f., III, I22 f. 
och traditioner. Fattigdom, missväxt och tiggeri hade länge utgjort grogrund för magisk skadegörelse i lokalsamhället. Under i8oo-talet började emellertid fattigdom definieras som ett samhälleligt problem som skulle lösas, och den fick en ny, utländsk och vetenskaplig benämning, "pauperismen". ${ }^{81}$ Ondskans problem var en central fråga i övergången mellan olika trossystem och samhällssystem under i8oo-talet, och ondskans manifestationer blev föremål för intensiv debatt. Den debatten fördes inte minst i tidens skönlitteratur.

Störst utrymme hos Almqvist ges den"svenska" häxan Ellin, egentligen från Kronobergs län, i samtidsromanen Tre fruar i Småland. Almqvist gör stor affär av den "Kronobergska raçen" - särskilt högvuxen - men även ett finskt påbrå antyds. Ellin stammar också ur det småländska läseriet; hennes far organisten framställs som en person med djupa religiösa insikter. ${ }^{82}$ I romanens nutid livnär sig emellertid Ellin på trolldom. I inledningen upprättas en etnisk häxtypologi. Walter Scotts romaner har inspirerat flera häxor i urvalet, och Almqvist hävdar med uttrycklig referens till Scott:

att Skandinavien hyser lika så förträffliga troll, lika utmärkta plågoandar, som trotts nånsin Skottland. Våra torde väl mest [...] vara att träffa ibland lemningarne af det uråldriga Finn- eller Lappfolket, som bebor våra ödsligaste skogar. Men äfven ibland Svenskorna sjelfva saknas icke hexartade figurer, tre alnar långa, hemma i mörka konster, afskyvärda om man så behagar, men i motsatt fall intagande. ${ }^{83}$

Samer och finnar pekas ut som de äldsta folken med överlägsen tillgång till forntidens magiska kunskaper, en uppfattning som delades av bland andra Erik Gustaf Geijer och arkeologen Sven Nilsson. ${ }^{84}$ Ellin

8I. Stark, The Magical Self, bl.a. s. I86-I90, 253; Porter,"Witchcraft and Magic", s. I96.

82. C.J.L.Almqvist, Tre fruar i Småland. Samlade verk 25, utg. Lars Burman, Stockholm: Svenska Vitterhetssamfundet 1998, s. 228. Om etnicitet och landskap i Tre fruar, se Bohlin, "Den svenska I840-talsromanen som nationell kartografi".

83. Almqvist, Tre fruar, s. 48. Walter Scott var en inspiration för alla författare i urvalet; om Scotts betydelse för Topelius se t.ex. Mari Hatavara, "History, the Historical Novel and Nation. The First Finnish Historical Novel as National Narrative", Neophilologus 86 vol. I, 2002, s. Io, https://doi.org/Io.IO23/a:IoI2916401385.

84. Aspelin, "Det europeiska missnöjet", s. 221. 
talar dock"sin rena småländska": hon är svensk. ${ }^{85}$ I romanhandlingen ställs den kronobergska/svenska/finska Ellin mot romska Maguellone.

En utförlig beskrivning av lövjeri visar Ellin i färd med att signa en kolmila. Utrustad med kniv, järnspett och en död katt mässar hon olika delar ur psalmer på "den mest antika småländska”, obegriplig för huvudpersonen Medenberg. ${ }^{86}$ Bonden är pressad av överhet och länsman: milan måste producera mer för att barnen inte ska svälta och han själv tvingas ta sitt liv i förtvivlan. Bevekad av bondens nöd går Ellin med på att utföra riten ytterligare en gång för att öka utkomsten, men innan hon hinner skrida till verket blir sällskapet"ertappadt midt i sin hedendom". ${ }^{87}$ Trolldomen blir onödig när Medenberg lovar att utverka lättnader i herrgårdens krav.

Magin som utjämnar social orättvisa får dock en motvikt i magi som förförelse och förräderi. Den småländske slagskämpen Göran blir uppsökt i skogen av någon som han först tror är skogsrået, men som visar sig vara romska Maguellone från Skåne. Till skillnad från Ellin är hon inte kristen, men hennes tillvägagångssätt är en direkt parallell till Ellins när hon försöker snärja Göran för att hjälpa ett gäng bovar anförda av hennes bror. Rökpulver i elden, opium i vinglaset, hennes skönhet, dans och främmande sånger förtrollar Göran nästan till medvetslöshet. Elden, sången, riten - även ett obegripligt språk utgör en motbild till den svenska häxans magi. På typiskt almqvistskt manér ingår nämligen en lektion i "tjufspråket" i förförelseakten.$^{88}$ Förräderiet misslyckas och Maguellone dör av sitt eget gift. Kärleksmagi och förgiftning hörde till den traditionella magiska repertoaren, men hos Almqvist framställs de som skadegörelse genom att förknippas

85. Almqvist, Tre fruar, s. 48. Almqvist var inspirerad av sin vän Peter Wieselgren, som kopplade kvinnovänliga arvslagar i Värend i Småland till häxor, vilka han uppfattade som en kvarleva från en "för-odinsk" moderskult. Karin Westman Berg, Studier i C.J. L. Almqvists kvinnouppfattning, Göteborg: Akademiförlaget Gumperts 1962, s. 367-369, 4I3 f., se citat på s. 4I3. Se även Aspelin, "Det europeiska missnöjet", s. 208; Lars Burman, Tre fruar och en mamsell: om C.J. L. Almqvists tidiga I840-talsromaner, Hedemora: Gidlunds förlag I998, s. I87.

86. Almqvist, Tre fruar, s. 315. Lövjeri betecknar i de gamla trolldomskategorierna rituella handlingar. Oja, Varken Gud eller natur, s. 23.

87. Almqvist, Tre fruar, s. 3 I8.

88. Ibid., s. 403 . 
med något utländskt och konstfullt - "ambrosisk vällukt", kvinnor på "etruskiska vaser" och "Faraoniska taflor" ${ }^{89}$

Almqvists"goda" svensk-finska häxor använder magi för att avvärja hungersnöd; de konfronterar med andra ord pauperismen, ett problem som engagerade Almqvist djupt. ${ }^{90}$ Almqvists songe inspirerade senare August Strindbergs historiska berättelse "En häxa”, en levnadsskildring som visar hur samhällets klassförtryck och dubbelmoral bryter ner individen, och som har betydande likheter med samhällskritiken i författarskapet som helhet. ${ }^{91}$ Medan häxan i Strindbergs sena I80o-talstappning får gestalta individens kamp mot samhället, har Almqvists häxor vidare implikationer för medborgarskap och nation.

Fattigdom var inte bara en nationell katastrof i samtiden, utan också något som paradoxalt nog enligt Svenska Fattigdomens betydelse (I838) präglar det svenska folket i positiv mening. Svensken, hävdar Almqvist, är den enda nationalitet som Gud har ämnat för fattigdom, det vill säga "att kunna vara fattig. Att kunna det rätt, med fullkomlig frihet, raskhet och sjelfständighet [...]."92 Programskriften fick stor betydelse: den trycktes om många gånger in på igoo-talet och inspirerade såväl författare som andra opinionsbildare. Exempelvis fick Almqvists skrift betydelse för Artur Hazelius beslut att skapa friluftsmuseet Skansen med gamla bondstugor och för Runebergs behandling av den finska fattigdomen i den episka dikten Julqvällen (184I). ${ }^{93}$ Att Almqvists häxa gestaltar nationalkaraktären blir uppenbart i beskrivningen av Ellins vackra dotter, som bär samma namn som sin mor. Dottern har vid sidan av sin mors magiska färdigheter

89. Ibid., s. 400; Oja, Varken Gud eller natur, s. 57 f.

90. Om pauperismen och Svenska Fattigdomens betydelse, se Aspelin, "Det europeiska missnöjet", s. 185-200. Om pauperism, se även Klinge, Idyll och hot, s. 353 .

91. August Strindberg,"En häxa”, Svenska öden och äventyr II. August Strindbergs Samlade verk I4, utg. Bengt Landgren, Stockholm: Norstedts förlag I990, s. 90-I6I.

92. C.J.L. Almqvist,"Svenska Fattigdomens betydelse", C.J.L. Almqvist, Törnrosens bok VIII-XI, Samlade verk 8, utg. Bertil Romberg, Stockholm: Svenska Vitterhetssamfundet I996, s. 290.

93. Jon Viklund, Ett vidunder i sitt sekel. Retoriska studier $i$ C.J.L. Almqvists kritiska prosa I8I5-I85I, Hedemora: Gidlunds förlag 2004, s. I64-I67; Claudia Lindén,"Den hemliga länken. Almqvist, Key, Skansen och rösträttsrörelsen”, Anders Burman \& Jon Viklund (red.), Almqvistvariationer. Receptionsstudier och omläsningar, Göteborg \& Stockholm: Makadam förlag, under utgivning, utkommer år 2or8; Wrede, Världen enligt Runeberg, s. 218, 237-244. 
ärvt sin morfar organistens religiösa sinne. Framför allt är hon fattig: "Hon egde genom sin beskaffenhet, att älska arbete och hvarken frukta för tjenst eller sysslor, ett oberoende, som ställde henne alldeles fri för nöd och behof." ${ }^{4}$ Häxans dotter representerar det svenska folket och ger därmed nationen röst. I slutet av romanen bidrar hon till att omvända småländska rövare, som drivits till stöld av orättvis lagstiftning. Målet är att de forna rövarna ska delta i samhället som hederliga medborgare.

Magi som lösning på social nöd gestaltar en central aspekt av berättelsen om nationen hos Almqvist. Han ger ett omvänt perspektiv på den religiösa konflikten och argumenterar för att den kristna människokärleken återfinns i magin, i motsättning till den lag som ”ännu är helt och hållet hednisk till sin grundsatts, stridande emot christendomen, som vill, att ingen borttappad skall gå förlorad" ${ }^{95}$ I Almqvists logik är det Svea Rikes Lag som präglas av hedendom, eftersom den motarbetar häxans medborgerliga hjälpverksamhet.

\section{TOPELIUS MAgi: GeStALTNING AV NATIONENS Historia}

I Topelius historiska romaner är häxans relation till medborgarskapsdiskussionen mindre tydlig, men magin är mer kraftfull: häxan Waapuri i Hertiginnan af Finland har makt över väder och vind, och hennes spådomar slår in. Även Waapuri utövar förvisso vit magi. Hon kan "trolla god smörlycka" och har hjälpt romanens borgmästarinna att återfinna stulna ting, men hon gör sig också tveklöst skyldig till maleficium, dock inte djävulspakt. Häxan åkallar inte Satan utan Ukko. ${ }^{96}$ När läsaren första gången möter Waapuri mumlar hon ”en finsk trollruna" som manar fram ett oväder. Den "gula vissnade hyn och de rödsprängda, fastän ytterst hvassa och genomträngande ögonen” poängteras genom hela romanen. ${ }^{97}$ Dagens läsare har lätt att

94. Almqvist, Tre fruar, s. 459.

95. Ibid., s. 4I9. Om det hedniska i samhällsinstitutionerna, se Anders Burman, Politik i sak, s. 186 f.; Aspelin, "Det europeiska missnöjet", s. II3-I20.

96. Zacharias Topelius, Hertiginnan af Finland och andra historiska noveller, Zacharias Topelius Skrifter V, utg. Pia Forssell, Helsingfors: Svenska litteratursällskapet i

Finland / Stockholm: Bokförlaget Atlantis 2013, s. 96.

97. Ibid., s. 93, 98, пr6 f., I36, I6r. 
missförstå Waapuri utifrån myten om häxan som en stackars gammal, försvarslös kvinna, men ı8oo-talets läsare hade bättre förutsättningar att identifiera vassa ögon som tecken på trolldomsmakt. Aggressivitet och kraftfull blick var viktiga verktyg för att kunna utföra magi. ${ }^{98}$ I Topelius novell "Trollkarlens dotter" (I845) finns en utförlig beskrivning av en tietäjä som på traditionellt vis försätter sig i trans genom att stampa med fötterna, samtidigt som han med fradgande läppar sjunger runor hämtade ur Kalevala. ${ }^{99}$ Dottern är i själva verket en förrymd fransyska och novellen en kärlekshistoria som utspelar sig i Karesuando I795, men magin avfärdas inte. I trans förutspår denne tietäjä Frankrikes framtid efter revolutionen.

Den romantiska historieskrivningen, som Topelius anslöt sig till, framställde folk som ett slags levande personligheter. ${ }^{100}$ En tidig romantisk historiker, fransmannen Jules Michelet, skulle några år senare publicera sin inflytelserika studie La sorcière (I862), som felaktigt framställer häxan som ett slags gudinna i en uråldrig fruktbarhetsrit och ett uttryck för folklig protest mot överheten. ${ }^{101}$ Waapuri är knappast någon fruktbarhetsgudinna, men hon har det gemensamt med Michelets något senare häxa att hon representerar en befolkning. Matti Klinge och Mari Hatavara har argumenterat för att romanens huvudperson Eva Merthen på olika sätt representerar nationen. ${ }^{102}$ Min avsikt är att peka på att även häxan Waapuri bär berättelsen om nationen.

Ovädret Waapuri trollar fram i Hertiginnan af Finland identifieras med krigsutbrottet I74I. I första delen av romanen argumenterar Tope-

98. Stark, The Magical Self, s. 219-223, 286-306.

99. Zacharias Topelius, "Trollkarlens dotter", Noveller, Zacharias Topelius Skrifter IV, utg. Pia Forssell, Helsingfors: Svenska litteratursällskapet i Finland / Stockholm: Atlantis 2012, s. 67-86, se även Pia Forssells kommentar s. 302.

Ioo.Klinge, Idyll och hot, s. I6o-I74. För en diskussion om gestaltningen av nation i Topelius och Fredrika Runebergs historiska romaner se även Hatavara, "History, the Historical Novel and Nation", s. I-I5.

Ior. Se vidare om detta, t.ex. Ankarloo, Satans raseri, s. 279; Diane Purkiss, The Witch in History. Early Modern and Twentieth-Century Representations, London \& New York: Routledge i996, s. 34 f.

I02. Klinge, Idyll och hot, s. 248 f.; Mari Hatavara refererad av Forssell i Forssell \& Klinge, "Inledning”, Zacharias Topelius, Hertiginnan af Finland och andra historiska noveller, Zacharias Topelius Skrifter V, utg. Pia Forssell, Helsingfors: Svenska litteratursällskapet i Finland / Stockholm: Atlantis, s. XVII. 
lius för att Sverige inte hade förmåga eller vilja att försvara Finland. Att spara Sverige och svika Finland var, enligt Topelius,"den hemliga tanken hos de fleste af [rikets] herrar","den dolda nyckeln till många gåtlika rådslag" - "detta fattiga, aflägsna Finland, som i alla krig hade för Sverige gjutit sitt hjerteblod och offrat sin sista skärf" ${ }^{103}$ I andra delen beskrivs häxans skadegörelse som en begriplig hämnd för de grova orättvisor hon och hennes släkt blivit utsatta för i generationer. Maija Lehtonen diskuterar Topelius häxor i samband med skräckromantiska drag i författarskapet, och även om hon påpekar att Waapuris trolldom är en hämnd, uppfattar hon överlag magin som fantasifoster till följd av psykisk sjukdom, vilka omgivningen suggereras att tro på. ${ }^{104}$ Jag vill i stället undersöka magins nationalistiska funktion.

Waapuri förutspår att ovädret, kriget och pesten hon trollat fram ska "förgöra detta förbannade land" och säger om sig själv:

Då skall hon ropa till de höga herrarne: hafven J icke brännt på bålet min moder och min mormoder och min moders mormoder? Hafven J icke låtit piska mig med ris och släpat mig från häkte till häkte för en liten smula trolldoms skull, för några fattiga fyrkar tjufgods, som jag skaffat tillrätta med signeri. Och nu sednast, har icke er borgmästare driffvit min dotter, min Lisu, i nöd och elände ifrån mig, blott för det att hon var min dotter? Har han icke låtit jaga mig som en tatterska från staden, för det jag spått i hand och för det frun påstår att jag med ormskinn trollat hennes kor att mjölka blod och satt uppå henne gikt med de dödas ben insydda i hufvudkudden? ${ }^{105}$

Hämnden riktar sig specifikt mot "de höga herrarne", och deras agerande är den direkta anledningen till att hon också hjälper den ryska armén; hon vill att staden Åbo och hela Finland ska brinna såsom hennes förmödrar har brunnit. Häxan får därigenom representera en

I03. Topelius, Hertiginnan af Finland, s. 42 f., 55, se även kommentar av Klinge i Forssell \& Klinge, "Inledning", s. XVIII.

I04. Maija Lehtonen, ”Den topelianska världsbildens mörka sida. Topelius och skräckromantiken", Historiska och litteraturhistoriska studier 70, Helsingfors: Svenska litteratursällskapet i Finland (SLS) I995, s. 22 f.

I05. Topelius, Hertiginnan af Finland, s. 94. 
hel befolkning, misshandlad av rikets ledning i Stockholm som lät Finland brinna om och om igen under I70o-talets krig mot Ryssland. Vägen framåt är emellertid, enligt romanen, försonande, kristen kärlek. Anttonen lyfter fram att Lönnrot konstruerade Kalevala i enlighet med en protestantisk utvecklingstanke som osynliggjorde landets katolska och ortodoxa historia, och lät ett hedniskt förflutet peka fram emot en lutheransk samtid. ${ }^{106}$ Topelius gestaltar samma tankefigur när Waapuri, efter att hon har förföljt Eva Merthen genom hela romanen och utsatt henne för oräkneliga faror och sorger, i slutet bekänner sina trolldomsbrott, blir förlåten av Eva och omvänds till tron på Gud. Poängen är knappast att ge en realistisk skildring, men däremot att gestalta nationen.

I andra cykeln av Topelius släktepos om Finlands historia, Fältskärns berättelser, undersöks grundligt"de hemska vanvettiga hexprocesserna" under I60o-talet. ${ }^{107}$ Finland kallas för"trolldomens hemland sen urminnes tid" och Topelius hävdar att "i Sverige behöfdes icke mer än att vara finska och vara gammal och ful" för att anklagas för trolldom. ${ }^{108}$ Modern forskning visar att denna överdrift inte är riktigt så stor som man kan tro. Historikern Linda Oja skriver att

ett sätt att ange att en person var magikunnig var att benämna henne eller honom lapp, finne eller kommande från Norrland. Huruvida det verkligen rörde sig om samer, finnar och norrlänningar går oftast inte att avgöra. I vissa fall står det klart att det inte gjorde det. ${ }^{109}$

Io6.Anttonen, "Oral Traditions and the Making of the Finnish Nation", s. 339 f. Se även Juha Pentikäinen, "Arctic Shamanhood. Questions on the Interpretation of Sacred Singing, Language and Knowledge of 'Those Who Know the Ways of Shamanism"', Birger Winsa (ed.), Finno-Ugric People in the Nordic Countries. Roots V: The Roots of Peoples and Languages of Northern Eurasia, Hedenäset: Lumio förlag 2005 , s. $34 \mathrm{f}$.

I07. Zacharias Topelius, Fältskärns berättelser, Zacharias Topelius Skrifter VII, utg. Sebastian Köhler \& Anna Movall under medverkan av Pia Forssell, Helsingfors: Svenska litteratursällskapet i Finland 20I8, s. 288. Genom en särskild vänlighet av Pia Forssell och Sebastian Köhler fick jag i förväg tillgång till den färdigetablerade texten till Skrifter.

108. Topelius, Fältskärns berättelser, s. 318 .

I09. Oja, Varken Gud eller natur, s. I7I f. 
Att samer och finnar var särskilt utsatta för trolldomsanklagelser vittnar också statistiken om; exempelvis fick den danske kungen Christian IV:s uppmaning år I6o9 om särskild vaksamhet på trolldom hos finnar och samer i norska Finnmark genomslag i ett ökat antal domar. ${ }^{110}$ Även Waapuri i Hertiginnan af Finland går under beteckningen "Lappqvinnan". ${ }^{111}$ I Fältskärns berättelser utnyttjar general Bertelsköld dessa fördomar för att vinna militärt övertag i Litauen genom att sprida trolldomsskräck. Intrigen i verket som helhet bygger också på en magisk ring.

Häxan blir dessutom huvudperson i den femte berättelsen med rubriken "Hexan”. Svarta Jane livnär sig, liksom Almqvists Ellin, på vit magi och vägrar följa sina grannars uppmaning till djävulspakt. Hennes ursprung är varken finskt eller samiskt - hon visar sig härstamma från Bayern och vara trogen sin katolska tro, vilket är anledningen till att hon undvikit den lutherska mässan. Topelius följer en vanlig protestantisk förklaringsmodell från I70o-talet och framåt, som relaterar vidskepelse till kvardröjande katolska föreställningar. ${ }^{112}$ Orsaken till att Svarta Jane ställs inför rätta och utsätts för vattuprov är hennes moderliga omsorg om tre barn som gått vilse i skogen. Uppskrämda av häxryktet omtolkar barnen Janes omhändertagande i enlighet med berättelser om häxsabbat på Blåkulla. De vågar inte äta av den goda mat Jane bjuder på av rädsla för att brödet och filbunken ska förvandlas till mask. Topelius framställer barnens skräck som ett vittnesbörd om tidsandan:"När en idé, en fördom eller hvilken föreställning som helst har gripit ett folk, så skall man grannt märka dess omfång och vigt $\mathrm{i}$ de små barnens mun." ${ }^{113}$ Efter en utförlig skildring av rannsakningen $i$ protokollform, döms Jane för" hednisk trolldom, djefvulens umgänge" och dessutom för papism. ${ }^{114}$

Topelius betonar framför allt bristen på medlidande:

IIo. Willumsen, Witches of the North, s. 259; Rune Blix Hagen,"Witchcraft and Ethnicity: a Critical Perspective on Sami Shamanism in Seventeenth-Century Northern Norway", Marko Nenonen \& Raisa Maria Toivo (eds.), Writing Witch-Hunt Histories. Challenging the Paradigm, Leiden \& Boston: Brill 2014, s. I4I-I66.

III. Topelius, Hertiginnan af Finland, s. 97.

II2. Se t.ex. Oja, Varken Gud eller natur, s. 89.

II3. Topelius, Fältskärns berättelser, s. 318.

II4. Ibid., s. 336 . 
Så förvildade voro redan sinnena genom dessa vidunderliga, tätt på hvarandra följande hexprocesser; så förvirrade voro genom dem begreppen om mensklighet och medlidande, att man trodde sig göra Gud en tjenst med att håna den olyckliga i hennes skymf och förnedring. ${ }^{115}$

Den efterföljande diskussionen på berättandets nuplan understryker skillnaden mellan nutid och dåtid, och slår fast att trolldom är "för en christen menniska vederstyggeligt skrock", men magi avfärdas inte helt. ${ }^{116}$ När Jane räddats ur sitt fängelse avslutas berättelsen med att hon spår Finlands framtid i havet:"Långa smärtor och sena fröjder". ${ }^{117}$ Hos Topelius hör magi till ett förflutet som övervunnits; trolldom har ersatts av rationalism och lutherdom. Trots det får trolldomskunniga personer uttala nationens öde och representera finska folket. Trolldom omfattar därmed även här nationalismens alla tre tider. Magiska föreställningar får visserligen inget utrymme att verka i framtiden, men förutsäger den likafullt som vision.

\section{HÄXAN: NATIONENS RÖST}

Vid mitten av I80o-talet flyttades magiska föreställningar ur etnografiskt material in i skönlitteraturen och häxan gavs en ny funktion i nationens tjänst. Anttonen påpekar att den nationalistiska etnografin hämtade föremål och berättelser från nationens utmarker och flyttade in dem i museer och moderna publikationer. Kulturella uttryck från modernitetens marginaler omformulerades till nationens symboliska centrum. ${ }^{18}$ Samtliga författare i urvalet knyter an till föreställningen om trolldomens etniska koppling till finnar och samer - alla utom Wacklin, som endast berör dessa fördomar indirekt. Det innebär emellertid inte att häxan hos Bremer och Almqvist skiljs ut som "den andre", tvärtom gör de båda anspråk på magin som det egna och inkluderar åtminstone det finska arvet. Topelius hävdar stolt egendomsrätten till

\footnotetext{
II5. Ibid., s. 326.

II6. Ibid., s. 343 .

II7. Ibid., s. 340 .

II8. Anttonen,"Oral Traditions and the Making of the Finnish Nation", s. 330.
} 
magin och ger en samisk tietäjä kraft att förutspå framtiden. Olika etniciteter inkluderas i magins nationsbyggande funktion.

Alla dessa fyra författare engagerade sig också för kvinnors rättigheter. ${ }^{119}$ I viss mån är de föregångare till r970-talsfeminismens användning av häxan i debatten om makt och samhällsdeltagande. Diane Purkiss visar hur häxan blev ett kraftfullt identifikationsobjekt för I970-talets kvinnorörelse och en kvinnohistoria som undersökte patriarkalt förtryck. ${ }^{120}$ I80o-talets litterära häxor är dock knappast offer utan handlingskraftiga personer med magisk makt. Purkiss utvecklar också hypotesen att häxförföljelserna bottnade i skräcken för häxan som ett slags anti-mor, en motbild till den goda husmodern. ${ }^{121}$ Med undantag för Wacklins häxor, framhävs dock just moderligheten hos alla häxor i urvalet, inklusive Topelius manliga tietäjä i "Trollkarlens dotter”. Det väcker frågan om häxans relation till I8oo-talets kvinnliga personifikationer av nationen, Finlands mö och Moder Svea.

En storvuxen manlig tietäjä, som arbetar upp sig till raseri för att utöva magi, är kanske så långt ifrån Finlands mö som man kan komma. Johanna Valenius framhåller att Finlands mö, till skillnad från den näringsgivande Moder Svea, oftast utmålades som jungfru, föremål för heterosexuellt begär, potentiell brud och mor, samt utsatt för hot om sexuellt våld. ${ }^{122}$ Waapuri och Svarta Jane är dock allt annat än försvarslösa; de är helt fria från patriarkala band samt utgör inte objekt för heterosexuellt begär. Under I8oo-talet framställdes ofta Finlands mö som dotter till Moder Svea och styvdotter till Moder Ryssland. ${ }^{123}$ Det understryker att personifikationen gällde nationen som territoriell och politisk enhet, vilket också förklarar varför Topelius, Wacklins eller Almqvists häxor egentligen inte kan relateras till Finlands mö respektive Moder Svea. Deras häxor representerar på olika sätt idén om folket snarare än territoriet eller staten. Bremers

II9. Klinge, Idyll och hot, s. 26 f., 347 f.; Helena Westermarck, "Sara Wacklin", Sara Wacklin, Hundrade minnen från Österbotten, utg. Helena Westermarck, Stockholm: Björck \& Börjesson I920, s. 7-66; Westman Berg, C.J. L. Almqvists kvinnouppfattning; Carina Burman, Bremer. En biografi.

I20. Purkiss, The Witch in History, s. 7-88.

I2I. Ibid., s. 9I-I44.

122. Johanna Valenius, Undressing the Maid. Gender, Sexuality and the Body in the Construction of the Finnish Nation, Helsinki: Suomalaisen Kirjallisuuden Seura 2004. I23. Ibid., s. II2 $\mathrm{f}$. 
Siri och Sofia kommer tvärtom mycket nära framställningen av Moder Svea i Bremers egen roman Midsommar-resan (1848). Det är ingen slump. Moder Svea förkroppsligar territoriet. ${ }^{124} \mathrm{Häxan} \mathrm{får} \mathrm{en} \mathrm{liknande}$ nationalistisk uppgift, eftersom hon ger röst åt naturens själ - en av de aspekter som skiljer Bremers häxor från de andra exempel som behandlats här.

Häxan ger röst åt nationen och förhåller sig till medborgarskap på olika sätt i de fyra författarskap som studerats. Det innebär också att häxan placeras på olika tidsplan i nationalismens tredimensionella temporalitet. I Bremers författarskap framställs magin som avgörande för nationens framtid och individens frihet. Den fria kvinnliga medborgaren vitaliserar samhället genom förmågan att låta naturens hedniska röster komma till tals. Hedendom måste dock försonas med kristendom; Bremer uppfattar den hedniska tron som urtida aningar om den kristna trons evighet, som leder in i framtiden. Hos Wacklin är häxans relation till nationens framtid tvärtom negativt bestämd häxan tillhör enbart en förfluten tid och kan inte producera vare sig framtid, frihet eller sanning. Häxan har inga lärdomar att förmedla till framtiden, men bär fortfarande berättelsen om nationen. Magin förtjänar korrekt kulturhistorisk återgivning som ett visserligen passerat stadium men samtidigt avgörande steg i nationens utveckling. Häxan ger röst åt det förflutnas mörker mot vilket medborgarnas ljusa nutid och framtid avtecknar sig.

Hos Almqvist ger den goda häxan röst åt folkets karakteristiska egenskap: fattigdom. I samtiden är hennes magiska lösning på pauperismen fortfarande betydelsefull, men berättelsen antyder att ett mer rättvist samhälle kommer att göra trolldom onödig. Magin fungerar som ett led $i$ argumentationen för ett liberalt samhällssystem och häxans sociala ansvarstagande står för ett medborgerligt ideal. I Topelius historiska fiktioner är trolldomens relation till medborgarskap mer vag, och Waapuri och Svarta Jane representerar knappast finska folkets karakteristika, men däremot nationens historia. I enlighet med den romantiska historieskrivningens idé om nationen som en individ ger häxan röst åt nationens öden. Den profetiska gåvan är häxornas främsta förmåga hos Topelius. Därmed förbinds forntida besvärjelser

I24. Bohlin, "Den svenska I840-talsromanen som nationell kartograf", s. 67. 
med nationens framtida öden: häxan får uttala nationens framtid. I alla dessa författarskap blir häxan bärare av berättelsen om nationen och synliggör samtidigt skillnaderna i förståelsen av nationalismens temporalitet.

Relationen mellan magi och medborgare varierar: i Bremers författarskap öppnar magin för medborgarskap, medan de i Wacklins författarskap tvärtom ställs närmast antitetiskt mot varandra. Den eviga naturen eller den mörka bakgrunden till civilisationens framgångssaga, folkets karakteristika eller nationens öde - häxan tas i bruk för att gestalta olika och motstridiga aspekter av föreställningen om nationen i finländsk och svensk litteratur vid mitten av I8oo-talet. I det avseendet blottlägger häxorna sprickor i nationalismens myter: nationalismens tredimensionella temporalitet dras isär i kampen om det religiösa tolkningsföreträdet. 